The changing appearance of the physician in the history of opera

\begin{tabular}{|c|c|c|c|c|c|}
\hline Century & Role & Character & Role as physician & Basis of knowledge & Social position* \\
\hline 18th & Minor & Comic & None & Quackery & Inferior \\
\hline 19th & Minor and major & Comic/tragic & Clinical work & Magic potion/physical & Equal \\
\hline 20th & Major & Epic & Clinical work/research & Rational/biological & Superior \\
\hline
\end{tabular}

*In the context of the plot.

scientifically trained physician acting in a more sophisticated manner. The rise of competence, however, is paralleled by a rise in power with its potential to be used detrimentally. In the 20th century, the doctor often has a major role. He usually has high social standing, and, in addition to being a clinician, he is depicted as a researcher. The dynamics of the physician's role in the history of opera reflect the development of medicine and illustrate the development of the social position of doctors and the public attitude towards the medical profession over the past centuries.

Tonya Hongsermeier, Boston, and Peter Schmiedebach, Hamburg, provided valuable and insightful comments.

Competing interests: None declared.

1 Lederman RJ. Performing arts medicine. N Engl J Med 1989;320:246-8. 2 Sadie S, ed. The new Grove dictionary of opera. London: Maximilian Press, 1992.

3 Fielding JF. Myth, medicine and music. Irish J Med Sci 1990;159:77.

4 Baas HJ. Die geschichtliche Entwicklung des ärztlichen Standes und der medizinischen Wissenschaften. Berlin: F Wreden, 1986.

medizinischen Wissenschaften. Berlin: F Wreden, 1986.
Ober WB. Operatic “doctors." Practitioner 1976;216:110-6.

6 Goldovsky B. Some medical matters in operatic literature. Cleve Clin Q $1986 ; 53: 39-43$
7 Kümmel WF. Musik und Medizin. Freiburg/Munich: Karl Alber Verlag, 1977.

8 Bedford DE. The ancient art of feeling the pulse. Br Heart $J$ 1951;13:423-7.

9 Dauber LG. Death in opera: a case study, "Tales of Hoffmann"-Antonia. Am J Cardiol 1992;70:838-40.

10 Chesler E, King RA, Edwards JE. The myxomatous mitral valve and sudden death. Circulation 1983;67:632-9.

11 Malbeck ES. Ärzte, Krankheiten, Pharmaka. Die Verwendung medizinischer Elemente im italienischen, französischen und deutschen Opernlibretto des 19. Jahrhunderts [Dissertation]. Dusseldorf: University of Dusseldorf, 1971.

12 Boudalas H, Reynolds JC, Mazzaferri E, Wooley CF. Metabolic studies in mitral valve prolapse syndrome: a neuroendocrine-cardiovascular process. Circulation 1980;61:1200-5.

13 Willich SN, Maclure M, Mittleman M, Arntz HR, Muller JE. Sudden cardiac death. Support for a role of triggering in causation. Circulation 1993;87:1442-50.

14 Carmody J. Doctors and opera. Med J Austr 1991;155:783-4

15 Worth Estes J. The changing role of the physician in opera. Opera Quarterly 1994;10:143-55.

16 St Louis EK. The physician in contemporary opera: three divergent approaches to the doctor-patient relationship. Pharos 1992;55:15-20.

17 Klasen EM. Die Diskussion über eine "Krise" der Medizin in Deutschland zwischen 1925 und 1935 [Dissertation]. Mainz: University of Mainz, 1984.

18 Schmiedebach HP. Der wahre Arzt und das Wunder der Heilkunde. Erwin Lieks ärztlich-heilkundliche Ganzheitsideen. In: Abholz HH, Brocher T, Göbel E, eds. Der ganze Mensch und die Medizin. Hamburg: Argument-Verlag, 1989:33-53.

doi $10.1136 /$ bmj.39056.464074.55

\title{
Faints, fits, and fatalities from emotion in Shakespeare's characters: survey of the canon
}

\author{
Kenneth W Heaton
}

\section{Introduction}

The diseases mentioned in William Shakespeare's works have been much discussed, ${ }^{1-5}$ but another category of bodily change of medical interest seems to have escaped comment-the symptoms and signs induced by strong emotion in his characters. My interest in this topic was aroused when, studying Hamlet, I was struck by the violence of the hero's reaction to his encounter with his father's ghost on the battlements of Elsinore. Hamlet's anguished words, "Hold, hold, my heart, and you, my sinews, grow not instant old, but bear me stiffly up" (1.5.94; act, scene, line in Norton Shakespeare ${ }^{6}$ ), seem to suggest that his heart was palpitating and his knees were buckling. The symptoms suggest a near-syncopal attack or, conceivably, a paroxysmal tachycardia causing a drop in cardiac output. Continuing my studies of Shakespeare's plays and poems, I came across similar episodes, often involving actual loss of consciousness, and even several cases of sudden death, all occasioned by strong emotion. This prompted me to search systematically for bodily changes induced by emotion in the characters created by Shakespeare in his plays and long narrative poems. To put the findings in context, I examined in the same way some works by other playwrights active in the first half of Shakespeare's career.

\section{Methods}

Using a modern, annotated edition of the complete works of William Shakespeare, ${ }^{6}$ plus a monograph of Edward III, I read over a 20 month period every line of the 39 canonical plays and the three narrative poemsVenus and Adonis, The Rape of Lucrece, and A Lover's Complaint-mostly in chronological order, and systematically recorded every mention of a physical symptom or sign occurring in a character who was clearly experiencing strong emotion. Elsewhere, I have dubbed these phenomena "flags of feeling." ${ }^{\prime}$ They cover many systems of the body and, between them, attest to the playwright's acute awareness of the way the human body responds to emotion. Here I report the most dramatic of Shakespeare's flags of feeling: faints, fits, and death.

An extra table is on bmj.com 
Table 1 Plays in which a character dies from strong emotion*

\begin{tabular}{|c|c|c|}
\hline Play and reference $\dagger$ & Character dying & Emotion and its cause \\
\hline $\begin{array}{l}\text { Love's Labour's Lost } \\
5.2 .14\end{array}$ & Catherine's sister & Grief at unrequited love \\
\hline Romeo and Juliet 5.3.209 & Montague's wife & Grief at her son Romeo's banishment \\
\hline Othello 5.2 .212 & Brabantio & Grief at his daughter marrying Othello the Moor \\
\hline King Lear 5.3.195 & Gloucester & $\begin{array}{l}\text { Mixed grief at his blindness and joy at being reunited } \\
\text { with his son Edgar }\end{array}$ \\
\hline King Lear 5.3.309 & Learł & $\begin{array}{l}\text { Mixed grief at Cordelia's murder and hope that she } \\
\text { might still be alive }\end{array}$ \\
\hline $\begin{array}{l}\text { Antony and Cleopatra } \\
4.10 .22\end{array}$ & Enobarbus $\ddagger$ & Grief and shame at his desertion of Antony \\
\hline $\begin{array}{l}\text { Antony and Cleopatra } \\
5.2 .283\end{array}$ & Irasł & Grief at Cleopatra's imminent suicide \\
\hline The Winter's Tale 3.2.142 & Mamillius (child) & Grief at his mother Hermione's unjust imprisonment \\
\hline Cymbeline 1.1.37 & Posthumus' father & Grief at death of two sons in battle \\
\hline Cymbeline 5.6.26,57 & Queen & $\begin{array}{l}\text { Grief at her son's mysterious disappearance and } \\
\text { despair at her own homicidal wickedness }\end{array}$ \\
\hline \multicolumn{3}{|c|}{$\begin{array}{l}\text { "Lady Macbeth is omitted as she seems to commit suicide (Macbeth } 5.11 .36 \text { ); so, probably, does the } \\
\text { frenzied Lady Constance (King John 4.2.122; 3.4.105). The case of Cardinal Wolsey is debatable; he was } \\
\text { "broken with the storms of state" when he fell sick and died within a few days (All is True aka Henry VIII } \\
4.2 .15-30 \text { ). } \\
\text { †Plays are listed in order of composition. References (act, scene, line) are to the Norton Shakespeare. }{ }^{6} \\
\text { fDies on stage. }\end{array}$} \\
\hline
\end{tabular}

For context, I made a similar study of 18 works by playwrights active before 1600 (that is, contemporaries of Shakespeare who were least likely to show his influence). These were Christopher Marlowe (his six extant plays and the narrative poem Hero and Leander), John Lyly (Endymion, Gallathea, and Midas), Robert Greene (Friar Bacon and Friar Bungay and James the Fourth), John Marston (Antonio and Mellida and Antomio's Revenge), Thomas Lodge (The Wounds of Civil War and the prose romance Rosalynd), Thomas Dekker (The Shoemaker's Holiday), and Thomas Kyd (The Spanish Tragedy).

I searched in the chief sources of four plays for any mention of the deaths or faints featured in that play: for King Lear, the anonymous 1590 play The True Chronicle History of King Leir and his Three Daughters; for Antony and Cleopatra, Thomas North's translation of Plutarch's Life of Marcus Antonius; for Julius Caesar, Plutarch's Life

Table 2 Works in which a character faints from strong emotion

\begin{tabular}{|c|c|c|}
\hline Play or poem and reference* & Character fainting & Emotion and its cause \\
\hline $\begin{array}{l}\text { Two Gentleman of Verona } \\
5.4 .84\end{array}$ & Julia & Grief at lover's betrayal \\
\hline 2 Henry VI 3.2.32 & King Henry & Grief at uncle's murder \\
\hline 3 Henry VI 1.3 .9 & Rutland (child) & Fear of being murdered \\
\hline 3 Henry VI 5.5.43 & Queen Margaret & Grief at son's stabbing \\
\hline Venus and Adonis, line 645 & Venus† & Fear of Adonis' being gored \\
\hline 2 Henry IV 4.3.111 & King Henry & Joy at defeat of rebels \\
\hline Romeo and Juliet 3.2.56 & Nurse† & Horror at Tybalt's bloody corpse \\
\hline $\begin{array}{l}\text { Much Ado About Nothing } \\
\text { 4.1.107 }\end{array}$ & Hero & Shock at father's threatening to stab her \\
\hline Julius Caesar 1.2.245 & Julius Caesar†‡ & Excitement at offer of crown \\
\hline As You Like It 4.3 .155 & Rosalind & Horror at seeing Orlando's blood \\
\hline Othello 4.1.41 & Othello§ & Horror at Desdemona's "infidelity" \\
\hline King Lear 4.6 .41 & Gloucester & Belief that he had fallen off a cliff \\
\hline King Lear 5.3.217 & Kent† & Grief at Lear's madness \\
\hline Antony and Cleopatra 4.16 .70 & Cleopatra & Grief at Antony's "suicide" \\
\hline Pericles 22.34 & Thaisa & Joy at reunion with husband \\
\hline The Winter's Tale 3.2.144 & Hermione & Grief at son's death \\
\hline The Winter's Tale 5.2 .80 & Onlookers† & Grief at Hermione's death \\
\hline Cymbeline 4.2.334 & Imogen & $\begin{array}{l}\text { Horror at finding headless corpse wearing } \\
\text { husband's clothes }\end{array}$ \\
\hline
\end{tabular}

*Plays are listed in order of composition. References (act, scene, line) are to the Norton Shakespeare. ${ }^{6}$ †Faint off stage.

†Probably grand mal epilepsy; described as foaming at mouth, "falling sickness."

§Possibly grand mal epilepsy; called such by lago; also occurred the day before. of Julius Caesar; and for As You Like It, Thomas Lodge's Rosalynd.

In identifying the characters' emotions and their causes, I relied on a close reading of the text, informed by a Darwinian approach to the nature and nomenclature of emotion. ${ }^{910}$ I resolved obscurities in Shakespeare's texts by reference to other editions of his works (Arden, Oxford, New Cambridge) and to a compendium of Shakespeare's unfamiliar and misleading words. ${ }^{11}$

\section{Results}

Among several hundred flags of feeling in the works of Shakespeare, I discovered 10 instances of non-violent death in characters who, as far as one can judge, were not physically ill but were under severe emotional stress (table 1). They are a varied group, including women and men, a child, and a very old person. The one common factor is their emotional state-extreme grief. At least four of the deaths (those in King Lear and Antony and Cleopatra) are sudden, and three of them occur on stage. None of them is mentioned in the plays' chief sources.

Death as a possible consequence of extreme emotion is mentioned in the dialogue on 29 occasions (see extra table on bmj.com). Grief predominates again, but Shakespeare's characters believe other emotions besides grief to be potentially fatal: fear on two occasions, both in early works; anger on two occasions, both in late works; and even joy on two occasions, also in late works. The cause of this destructive joy is, in both instances, the recovery by an ageing father of a lost daughter, believed dead.

Table 2 shows the 18 occasions on which a Shakespearean character transiently loses consciousness while under extreme emotion. The incident is most often described-in a stage direction-as a character falling to the ground, with rapid recovery (seven occasions). The word "swooning" is used in six instances, "fainting" in five, and "trance" in two. In five cases, the onlookers at first think the person collapsing has died, but usually the episode is made light of, and twice it is dismissed as "womanish." In the case of King Henry IV, the faint begins with dimmed vision and giddiness, consistent with simple syncope (but, unlike all the other characters, he had been ill for a long time). With Julius Caesar and Othello, the illness seems to be epilepsy: Julius Caesar is said to foam at the mouth and to be prone to "the falling sickness," an old name for epilepsy; with Othello, epilepsy is confidently diagnosed by another character (Iago).

Emotion is explicitly blamed for the faint in six cases; with Gloucester in King Lear it seems to be the expectation of death. The responsible emotions varygrief is the most common (table 2), but positive emotions are present in the list (joy and excitement).

Near-fainting is described or mentioned on 13 occasions. The causes are again varied: fear (three cases); shame (three); grief (three); and anger, joy, excitement, and sexual desire (one case each). Facial pallor is described in one case (Love's Labour's Lost 5.2.392); in another, people close to others who are fainting are said to change colour (The Winter's Tale 5.2.80). 


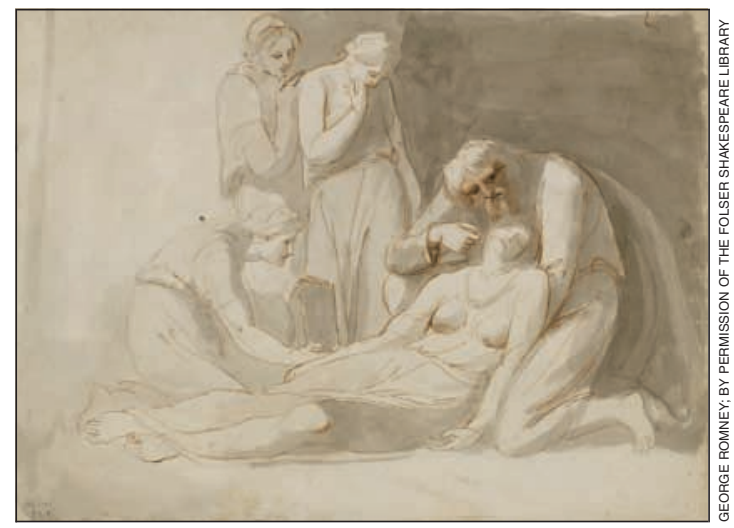

King Lear, about to be overwhelmed by Cordelia's death

Among the 18 works by Shakespeare's contemporaries, I found one actual death and seven imagined deaths from emotion. These are mostly from grief but also from fear and anger and, in two cases, from excessive joy (in Endymion and Antonio's Revenge). I also found three actual faints and one imagined one: two from grief and two from sexual desire (those in Endymion and Hero and Leander).

\section{Discussion}

This study has revealed a remarkable propensity for Shakespearean characters to die or faint, or to speak of these things as likely to happen, as a result of extreme emotion (or passion as it was called then). All but two of the 10 actual deaths, and all three of the staged deaths, occur in plays written towards the end of the playwright's life. Late plays are the only ones in which a major character dies in this way, and the play containing the most talk of death from emotion is Shakespeare's last but one solo work (Cymbeline). All this might prompt the speculation that, in his later years, Shakespeare was already contemplating his own demise, even though he was still in his $40 \mathrm{~s}$ (he died at the age of 52, for unknown reasons).

Besides actual deaths, Shakespeare's characters often speak of dying from strong emotion as a possibility, even a probability. Did Shakespeare himself believe that people die as a result of intense emotion, especially grief? The speaker in Sonnet 45 clearly does so: "My life ... Sinks down to death, oppressed with melancholy;" but a poem's speaker does not necessarily represent the poet himself. In the person of Rosalind, Shakespeare mocks the idea that a man can die of unrequited love: "The poor world is almost six thousand years old, and in all this time there was not any man died in his own person ... in a love cause" (As You Like It 4.1.81). Some of the claims of likely death in the table on bmj.com should be taken with a pinch of salt as poetic hyperbole or the fumes of an overheated romantic brain, but many cannot be so easily dismissed. Sometimes with Shakespeare, grief becomes fatal only when it is intensified by shock or horror, as in the experience of Lear.

The joy of Pericles and Cymbeline on recovering their daughters is so intense that they fear it might kill them. Shakespeare himself had two daughters, whose health must have caused him deep concern after his only son Hamnet died at the age of 11 in 1596 .
Elsewhere, an excitable young man (Troilus) is portrayed as being so anxious about his first love assignment that he fears dying through excess of pleasure. However, in Elizabethan slang, dying could mean orgasm. Christopher Marlowe is quite explicit that his fully aroused heroine faints at the entrance of her lover (Hero and Leander Sestiad 2.2).

Sudden non-violent death does occur in young people as well as older ones. Sometimes a cause is not found at autopsy, but recently a group of diseases has been identified that are believed to explain $30-40 \%$ of sudden deaths in young adults. These "ion channelopathies" affect the electrical functioning of a structurally normal heart. One of them, long QT syndrome, can cause sudden death "when a person is startled or suddenly awoken from sleep," and catecholaminergic polymorphic ventricular tachycardia is liable to occur "while the person is exerting themselves or suffering emotional stress."12 Extreme emotion can also lead to sudden death in people with subclinical cardiomyopathy or ischaemic heart disease, probably because of a ventricular arrhythmia caused by an outpouring of catecholamines. Such an outpouring can certainly lead to heart failure from myocardial stunning, even in people with apparently normal hearts. ${ }^{13}$

Knowing none of this, Shakespeare realised that extreme emotion can have powerful, indeed dangerous, effects on the human body. In this respect he was not unique. In Greek mythology, which pervades early modern writings, extreme emotion could lead not only to madness but also to a physical transformation (or metamorphosis), which, arguably, is akin to death. The fatal effects of too much joy, as well as too much fear, were described by the 10th century Arab physician, Haly Abbas. ${ }^{14}$ These effects must have been familiar to Elizabethan dramatists because, in Antonio's Revenge of about 1601, Andrugio is mendaciously reported as dying from the "vast delights of his large sudden joys." "14 In the play, these supposed joys follow a period of extreme anxiety, a mixture of positive and negative emotions that was considered especially dangerous. A similar mixture kills Gloucester in King Lear, where "his flawed heart-alack, too weak the conflict to support!'twixt two extremes of passion, joy and grief, burst smilingly" (5.3.309). Lear himself dies in a state of alternating despair and hope for the life of his beloved Cordelia.

Some of Shakespeare's deaths were not sudden. Leontes attributes the fatal illness of his son Mamillius to shame at the "dishonour" of his mother, but the royal servant is surely nearer the truth when he speaks of the child's fear for the fate of his unjustly imprisoned mother (3.2.144). In the other delayed deaths, the grief is explicit. Its cause is always the loss of a loved one and this loss is occasioned by rejection, banishment, imprisonment, and disappearance, as well as by bereavement.

Modern research has proved that mortality is increased among recently bereaved people. ${ }^{15}$ Whether emotional upset or the stresses of life without the loved one matters more is debated; Shakespeare seems to have had no doubt on this score. For example, a doubly bereaved father "took such sorrow that he quit being" (Cymbeline 1.1.38). Psychologists speak of the broken heart hypothesis, and bereaved people are indeed especially liable to a cardiac death. ${ }^{15}$ One argument for the broken heart hypothesis is the increased incidence 
of suicide after bereavement and here, again, Shakespeare has something to contribute, in the reported fates of Lady Macbeth and Lady Constance (table 1).

Shakespeare recorded fainting under strong emotion on 18 occasions. Nowadays called vasovagal syncope, this often causes myoclonic jerks, easily misdiagnosed as epilepsy. ${ }^{16}$ Emotional fainting is quite common, and its mechanisms are familiar-vagal bradycardia and hypotension from peripheral vasodilatation. In Marston's Antonio's Revenge, the Duchess of Genoa swoons when she hears that, contrary to what she had just been told, her missing husband is dead (another case of contrary emotions in dangerously quick succession). In the same play, the heroine Mellida swoons at the (false) news of her beloved Antonio being drowned and fails to recover consciousness; this was the one actual death from emotion that I came across in the works by Shakespeare's contemporaries.

Shakespeare had no hesitation in going for dramatic effect by adding a death, a fit, or a faint to a play when this was absent from his source material, even with overtly historical plays such as Julius Caesar and Antony and Cleopatra. He may even have been more prone to include such "flags of feeling" in his work than other writers of his day, but this survey can do no more than hint at this.

Does Shakespeare, with his unique insights into the human condition, ${ }^{17}$ have a message for today's doctors?
I think he does: never underestimate the power of the emotions to disturb bodily functions.

Competing interests: None declared.

Simpson RR. Shakespeare and medicine. Edinburgh: Livingstone, 1959. Edgar II. Shakespeare, medicine and psychiatry. London: Vision Press, 1971. Kail AC. The medical mind of Shakespeare. Balgowlah: Williams \& Wilkins, 1986.

Adams JC. Shakespeare's physic. London: RSM Press, 2000.

5 Foster J. A doctor's Shakespeare: a collection of medical quotations from Shakespeare. Xlibris.com, 2001

Greenblatt S, Cohen W, Howard JE, Maus KE, eds. The Norton Shakespeare. New York and London: Norton, 1997.

Melchiori G, ed. Shakespeare's King Edward III. New Cambridge edn. Cambridge: Cambridge University Press, 1998.

8 Heaton KW. Shakespeare's flags of feeling. A Groat's Worth of Wit (Journal of the Open University Shakespeare Society) 2006;17:32-5.

9 Darwin C. The expression of the emotion in man and animals. 3rd edn. London: HarperCollins, 1998.

10 Plutchik R. Emotion: a psychoevolutionary synthesis. New York: Harper and Row, 1980 .

11 Crystal D, Crystal B. Shakespeare's words: a glossary and language companion. London: Penguin Books, 2002.

12 Cardiac Risk in the Young. Sudden arrhythmias-what causes SADS? 2003. (www.sads.org.uk/causes_of_sads.htm)

13 Wittstein IS, Thiemann DR, Lima JAC, Baughmann KL, Schulman SP, Gerstenblith G, et al. Neurohumoral features of myocardial stunning due to sudden emotional stress. N EnglJ Med 2005;352:539-48.

14 Hoeniger FD. Medicine and Shakespeare in the English renaissance. London: Associated University Presses, 1992.

15 Stroebe MS, Stroebe W. The mortality of bereavement: a review. In: Stroebe MS, Stroebe W, Hansson RO, eds. Handbook of bereavement: theor research, and intervention. Cambridge: Cambridge University Press, research, and

16 Bergfeldt L. Differential diagnosis of cardiogenic syncope and seizure disorders. Heart 2003;89:353-8.

17 Bloom H. Shakespeare: the invention of the human. London: Fourth Estate, 1999.

(Accepted 21 November 2006)

doi 10.1136/bmj.39045.690556.AE
Loxhill, Surrey GU8 4BD

Michael O'Donnell

writer, broadcaster,

former $G P$

Correspondence to: mod@doctors.org.uk

BMJ 2006;333:1338-40

When the chairman of NICE phoned I assumed he'd called to confirm that I was no longer cost effective. Nothing so mundane. He announced that he and the editor of this journal were planning a reading of Bernard Shaw's The Doctor's Dilemma to celebrate the centenary of its first production. The performers would be medical persons of irrefutable distinction. Would I help?

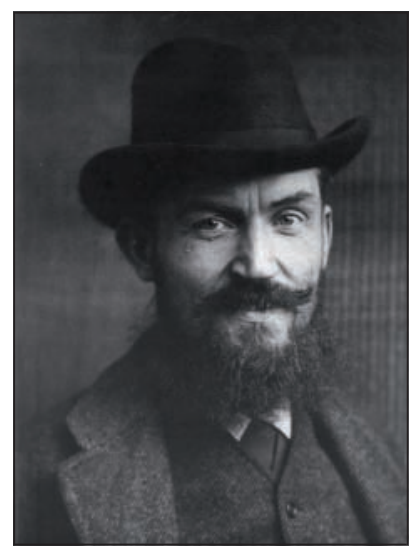

Seven weeks later, and dangerously close to the centenary date, my humble rural cottage was linked by conference call to two of the nation's medical powerhouses, the BMJ and NICE Supreme Command. Like the man in Mission Impossible, I was told that a theatre had been booked-well, a lecture theatre at the Royal College of Physicians-and my mission, if I was prepared to accept it, was to "adapt" the five act play for a not too arduous reading and to "direct" any members of the cast who could tear themselves away from busy lives for a moment or two of rehearsal.

I accepted the mission with delight. Bernard Shaw, about the time he wrote the play had appeared in-or, more often, stood in the prompt corner during-professional productions of half a dozen Shaw plays. I even starred in the Dilemma as the waiter who appears for 30 seconds at the end of act two and delivers the heart stopping line, "Yes, sir."

Listening from the wings to every scene, night after night, taught me that Shaw was a gifted maker of plays. I've little time for critics who dismiss him as a propagandist who used the theatre to broadcast social and political ideas. Of course the plays promulgate ideas but they are crafted so well and so wittily that they rarely fail to do what plays should do-engage the minds and emotions of an audience.

I decided to adapt the play as if for radio. We cut all theatrical "business" and the performers read their scripts from a row of lecterns. In rehearsal I didn't dwell on technique-or as doctors prefer "communication skills"-but encouraged the performers to do their stuff in their own way, intervening only to suggest a change of delivery to emphasise meaning or to inject variation into the long speeches, of which there were many-though not as many as there were before my "adaptation."

We had so little rehearsal I had doubts we'd get away with it. But doubt started to melt when we launched the first scene and I felt the audience respond. True they were a sympathetic bunch, and we 